\title{
Student's Self-Confidence Restoration with Peer Mentoring Strategy
}

\author{
Jusuf Blegur, \\ M. Rambu P. Wasak, \\ Faculty of Teacher Training and Education, \\ Artha Wacana Christian University, Kupang, Indonesia \\ Renya Rosari, \\ Faculty of Economics, Artha Wacana Christian University, \\ Kupang, Indonesia
}

Doi:10.19044/esj.2019.v15n19p129 URL:http://dx.doi.org/10.19044/esj.2019.v15n19p129

\begin{abstract}
The research objective is to restore students' self-confidence in learning process using peer mentoring strategies. The research design used is classroom action research by involving students who experience selfconfidence problems determined purposively (five participants). Data were collected using participant observation, in-depth interviews, and field notes. Data were analyzed quantitatively (frequence and percentage) and qualitatively using Creswell's model with seven segments of analysis, ranging from the process of collecting data to interpreting themes. The results prove that the efforts to restore students' self-confidence succeed in five strategies, including three initial strategies (cycle 1), forming limited and intimate group discussion, placing peers who inherit caring, supportive, and inspiring, attitude and providing clear or detailed assignments. While the next two strategies (cycle 2) are to give full trust to students to execute their duties in form of performance and to conduct evaluations based on improvement using students advantages. Consequently, the increase from the first cycle to the second cycle for each participant are $\mathrm{P} 1=18.75 \%, \mathrm{P} 2=17.1875 \%, \mathrm{P} 3=23.4375 \%, \mathrm{P} 4=$ $17.1875 \%$, and $\mathrm{P} 5=20.3125 \%$. Peer mentoring is very helpful for educators to share roles in an effort to improve student learning performance, for instance improving self-confidence. In addition, peer mentoring can be used by educators to improve the quality of learning in other aspects such as learning outcomes, social intelligence, transformational leadership, and so forth.
\end{abstract}

Keywords: Self-confidence, peer mentoring strategy 


\section{Introduction}

The constructivism approach is an approach focusing on students as centers in learning process. When the constructivism approach is implemented, students get the opportunity and are stimulated to learn in dynamic and innovative process in developing their potential by considering the previous understanding and social settings (Hanafiah \& Suhana, 2010:62; Kumar \& Teotia, 2017:135). Constructivism approach requires concept of students' activeness is higher during the learning. They try to build knowledge through the process of discovery and invention from various activities of investigating, finding, and of managing the materials in form of scientific papers and it is expected to be discussed. To support the smoothness of learning, educators facilitate students with various learning media (laptops, projecteors, laser pointers, journals, books, and proceedings, etc.) so that the presentation and discussion process can be done effectively, efficiently, and in quality.

The concept of SCL has been well implemented in which groups that have been scheduled based on consensus result are able to do their job well. Students in discussion groups work on and write scientific papers as well as are responsible for those before their peers and lecturers. This process requires good self-confidence, because post-presentation material is followed by an interactive and communicative process of discussion (questions, objections, clarifications, inputs, and critics) guided by a moderator (student). At this stage, students are tested for their self-confidence during learning. Selfconfidence is as an attitude that allows students to have a positive, optimistic, and realistic view on their own abilities (Reddy, 2014:56; Blegur, Mae, \& Souisa, 2018:75). Self-confidence is very helpful for students, because in any reason students are able to do what is planned, expected, and intended. As a result, self-confidence is considered as one variable that most affects learning activities (Al-Hebaish, 2012:60), for instance helping students to overcome communication anxiety (Wahyuni, 2014:50).

During the learning process, students, as speakers, questioners, and buffers, still experience problems with their self-confidence status particularly the speaker. His self-confidence irritation is clearly illustrated through his body expression and accent when arguing. There are some indicators that can explain the lack of students' self-confidence, such as: 1) Panic when criticized, 2) Exclusive toward suggestions and ideas coming from others, 3) Hurry in giving arguments, 4) Asking his friends to deliver their arguments, 5) Asking questions when there is "coercion" from educators or friends, 6) Not looking at others when arguing, 7) Monotonous and rigid in expressing material, and 8) Sweating when presenting scientific papers or asking questions. As the result the learning activities become less active and interactive to discuss and disseminate the discussion result from each study group. 
The students' success in arguing is not only determined by physical health, learning atmosphere, learning media, learning material, and audience, but also is influenced by stable self-confidence. This (self-confidence) becomes important, because as potential educators wherever they are, they always involve in interaction with other people surroundings. Moreover, students' self-confidence can be used to predict the accuracy of work, performance, and learning achievement (Kleitman \& Stankov, 2007:161; Dhall, 2013:555), because the cognitive meta-process also functions well (Kleitman \& Stankov, 2007:161). Good self-confidence also encourages students to be optimistic when completing tasks, responsibilities, and to have a competitive attitude (Wildan, Irawati, \& Arista, 2014:197), as well as predictors to other important elements, for instance predicting the academic achievement (Karimi \& Saadatmand, 2014:210), reducing cognitive anxiety (Hatzigeorgiadis, Zourbanos, Mpoumpaki, \& Theodorakis, 2009:186), affecting achievement motivation (Reddy, 2014:56), and increasing academic achievement (Hannula, Maijala, \& Poehkonen, 2004:17; Al-Hebaish, 2012:60; Dhall, 2013:385).

By looking back at previous facts (third paragraph, point four), normally in study group, there are students or other peers who are mature in their self-confidence, so that they are able to express their ideas during the discussion. This becomes a new model to be managed by applying peer mentoring strategy to foster self-confidence. Peer mentoring in education is a strategy of involving students who are more experienced in helping and guiding students who are less experienced. This process leads to learning and self-development, both mentor and they who are accompanied by (mentee) (Grimes, Baker, \& Kuczmarski, 2014:1287) with various collaborations that provide reinforcement to psychosocial amongst learners to have positive selfimage in order to change and develop more advanced. Peer mentoring, as an alternative strategy, is used to reduce anxiety and reduce stress when students go through their destructive experiences.

Peer mentoring becomes more general and perhaps it becomes effective way to facilitate knowledge creation and to share knowledge (Bryant, 2005:319) for there is informative transaction between the two sides so that both mentor and mentee give contribution to achieve the success (Cornu, 2005:355), as well as peer mentoring is able to fulfill psycho-social needs for learners (Allen, Russell, \& Maetzke, 1997:488; Grant-Vallone \& Ensher, 2009:637). With a supportive emotional condition, students focus more on improvement efforts due to the openness to receive input from their peers or their companion by increasing interaction between fellow students to be more communicative (Sprengel \& Job, 2004:246), preventing student tension (Grant-Vallone \& Ensher, 2000:637), improving competence (Badu, 2010:214), professionalism (Widarti, 2012:119), and self-confidence in class 
(Murni, Suswati, \& Solin, 2013:1). Peer mentoring is also proven to increase interest and independence in work (Rizka, 2013:161), as well as to build friendships among peers (Glass \& Walter, 2000:155).

\section{Method}

\section{Design}

Researchers adopted cycle model for classroom action from Kemmis and McTaggart to provide opportunities for researchers to explore patterns in peer mantoring that can restore students' self-confidence in learning process. This study allows researchers to be more open, creative, and flexible to the data found, whether from the results of peer records of mentoring activities carried out, the results of interviews about the strategies used in restoring selfconfidence, as well as observations about students' self-confidence during the learning process. This design makes students "activated" in discussions to give meaning toward an effort to restore their self-confidence which is packaged in a peer mentoring strategy.

\section{Participant}

Participants were five students (3 men and 2 women) who had problems with self-confidence. They are divided into five different groups (2 to 4 members per group discussion) while one of the peers pays attention to academic competence and is responsible for restoring participants' selfconfidence. In addition, to avoid awkwardness, peer who is responsible has emotional closeness with the participants so that there is openness in sharing information, accepting and following up on the solutions offered.

\section{Data Collections and Analysis}

The peers are tasked to help to restore participants' self-confidence by applying various techniques, such as in-depth interviews, direct observation, making field notes, and reflecting together with participants to measure the development of their self-confidence and the factors that influence or encourage the achievement of restoration process. The observation guide itself is developed from four indicators, including: 1) Believing in one's own abilities (1-4), 2) Taking step independently in making decisions (5-8), 3) Having a positive sense of self (9-12), and 4) Dare to express ideas (13-16). The research data was analyzed quantitatively (frequence and percentage) and qualitatively by adopting the model of Creswell's in order to provide pattern and/or procedural meaning from peer mentoring strategy during the restoration of participants' self-confidence. This stage of analysis involves seven stages, such as collecting raw data, preparing process, reading the entire data, coding data, describing in themes, associating, and interpreting themes. 
Table 1. Criteria for completeness of participant self-confidence

\begin{tabular}{lll}
\hline Grades & Interpretation & Decision \\
\hline $49-64$ & Good & Complete \\
$33-48$ & Fair & Uncomplete \\
$17-32$ & Poor & Uncomplete \\
$0-16$ & Very poor & Uncomplete \\
\hline
\end{tabular}

\section{Results and Discussion \\ Action for Cycle 1 \\ Limited and initimate peer group}

The placement of students who experience self-confidence in discussion groups was done secretly and was distributed to groups that are different from each other. This effort is intended to avoid the perception of "intimidation" and "discriminatory" among fellow students to those who experience a crisis of self-confidence. Therefore, when the distribution took place, participants did not think that the distribution of this group aimed to handle their self-confidence problems. Educators ensure that participants remain relaxed and friendly in their study groups. The group has also prepared a mentor (peer mentoring) who is responsible for diagnosing, investigating, and improving the self-confidence of students or peers. Indeed, the division of the group also concerns to the skills, readiness, professionalism, and emotional status of the mentor to ensure the achievement of his actions. In addition, the limited number of groups is also very helpful for mentors in controlling the discussion and mentoring the activities.

One of self-confidence issues is actually influenced by a poor culture of appreciation toward students' expression, for instance among fellow students (Blegur, Mae, \& Souisa, 2018:75). Thus, this becomes interesting reason in determining mentors during mentoring. Mentors must be emotionally intimate with participants so that there is no reluctance during supervision, evaluation, and discussion between the two such as the participant 1 (Female, 21 years) stated that: "What makes me have self-confidence is by having someone who always supports me and wants to share with me in various ways." Emotional attachment or intimacy greatly assists participants to perform confidently. This intimacy actually helps participants to express their feelings objectively and openly and also objectively and openly receives input from the mentor. Evaluation process becomes more effective, efficient, open and meaningful if there is openess and emotional support attitude (Burleson, 2003:1), and smooth interpersonal communication between the two parties (Hoover, O'Shea, \& Carroll, 1988:22).

This limited and intimate group also indirectly encourages participants to have a high commitment to complete every task, because feeling of reluctance of each other. This is motivated by the division of work tasks among group members who demand complete work (internal motivation), 
because they do not want to disappoint fellow group members and there is no feeling of guilt from themselves for their undisciplined actions (Wasak, Manggoa, \& Blegur, 2016:433). According to participant 2 (Female, 22 years): "A team must have a commitment to do everything well and correctly. It is called work in groups. And I believe that I have learned a lot in the group because of the openness among group members. This openness and cooperation also help me to be confident to work alone." Collaboration in groups actually provides an opportunity for the development of participants' self-confidence. They learn to reconstruct self-appreciation based on the beliefs or tasks they have. Participants demonstrate a strong relationship with personal growth from the mentoring process, such as mutual care, reciprocity, commitment to personal growth, as well as establish closer and stronger friendships (Glass \& Walter, 2000:155).

\section{Caring, supportive, and inspirational peers}

The social relations created by participants and mentors must be truly based on a high sense of caring and motivation so that the process of restoration of participants' self-confidence is more effective. Participants are given more space for expression so that they can independently assess their self-confidence capacity with the assistance from a mentor. Technically, the participants actually do not have an understanding of the discussion material, but they are just nervous to express or convey their ideas so that they need other people (friends) who are able to stimulate their self-confidence. This was stated by participant 1 (Female, 21 years) that: "I need a friend to support and increase my self-confidence because I do not feel confident if there is no support from people around me, especially from my close friends." Support from closest friends is more "valuable" because the support is sincere and also meaningful because the closest friend (mentor) directly perceives the events experienced by participants (empathy).

Support from close friends (mentors) is more motivating and fun for participants than other partners because their togetherness does not only take place outside the classroom but also takes place in classroom where they are able to support each other in positive way. Blegur, Wasak, Tlonaen, \& Manggoa (2017:37) have proven that disciplinary practices are also stimulated by students's effort to maintain and build their social relations. This means that the participants can also use the social relation for positive interests in study group. This is one of the reasons why the placement of an intimate mentor and the support and motivation from the mentor provides a strong intervention in changing students' learning behavior. Students can be bad because their close friends otherwise students can be better because of their close friends. As stated by participant 2 (Female, 22 years old), she explained 
that: "Friends are one of the encouragers making me more confident and encouraging me when I am sad and weak."

Placing the competent peers has helped participants become more confident in their activities. They will be present as an example or inspiration for participants who are truly motivated to change. Self-affirmation techniques are also used by participants to restore and strengthen their self-confidence, as was performed by participants 3 (Male, 24 years) as follows: "When I see other people able to develop their potential, it makes me think that we are both human beings why can't I? This really helped me to increase my selfconfidence." Self-affirmation techniques that participants use as a form of "provocation" are coming from themselves. Participants want to be better by advancing themselves with supportive and provocative questions and/or statements. Self-affirmation helps participants to restore their self-confidence due to besides to get external reinforcement, they try to convince and calm themselves before facing a task or performance during the learning process. Indeed, this process goes with the mediation from capable and professional mentors. Competent and professional mentors contribute indirectly the participants to a spirit of high change to improve their self-confidence to be equal to or even be better than their mentors.

Students' success or failure in completing task is often caused by other non-cognitive problems, including self-confidence, motivation, and perseverance (Lester, Garofalo, \& Kroll, 1989:75), even irritation of selfconfidence can inhibit students' self-actualization (Tlonaen \& Blegur, 2017:227). Thus, students must be placed in study groups having interpersonal relationships with certain characterization (Pearce, 2009:236), such as disciplined peers because it helps them build positive socialization (Blegur, Manu, \& Souisa, 2018:370), so that the peer mentoring process provides an interactive effect on fellow students (Sprengel \& Job, 2004:246). Students who are weak in self-confidence need support so that they can fight their discomfort when expressing. Support starts with verbal and non-verbal. Moreover, motivating actions are also needed as a follow up to the support the mentor has performed. The practical condition, of course, is that a mentor or other partner appears as inspiration when expressing. For instance, calmness in asking questions, demeanor in opinion, as well as detail in presenting material. These "three" moral segments contribute to the restoration of participants' self-confidence, because their actions are at the beginning (supportive), middle (motivating), and at the end of the segment (inspirational).

\section{Clear and detail assignment}

The participants will not know the capacity of their self-confidence when they do not get the task or responsibility in carrying out learning 
activities. Because when the tasks and responsibilities are carried out, participants' self-capacities will be identified, as expressed by participant 2 (Female, 22 years old) that: "I believe that self-confidence grows when I get an assignment." Some students miss assignments or responsibilities challenging answers to foster their self-confidence (Blegur, Mae, \& Souisa, 2018:75). If the task carried out with full effort, it is able to produce results and satisfaction will arise in the students (Blegur, 2017:40). When getting a clear assignment in presentation group, such as reviewing the material " $\mathrm{B}$ ", and other friends review the material " $\mathrm{C}$ ", and so on, the participants feel more confident to do it because there are clear and systematic work procedures (Hoover, O'Shea, \& Carroll, 1988:22). The task is not complicated because of the detailed instructions in investigation, discovery, and workmanship. For example when participants get used to making presentations as assignments, then they begin to exercise their self-confidence. In addition, with clear or detailed work assignments, participants do not "over lap" when completing their responsibilities for the learning activities they undertake. Participants focus more on certain material that will be studied.

A clear work assignment is to assest self by compiling the material in detail along with its indicators and concrete examples so that participants can simplify questions or answers when the presentation is carried out. In addition, the role of the mentor is to divide the tasks of the participants based on their academic capacity in order to not to widen the gap between expectations and reality. This method is not"discrimination", but rather an effort to restore students' self-confidence from simple task distribution to complex tasks. As stated by participant 4 (26 years) that: "A task that suits my ability is the task that makes me more improve in educational process of." Participants who are involved in learning activities need a process for gradual change, particularly things relating to performance which tends to be "unfamiliar" to students. Clear distribution of tasks bridges participants to restore their self-confidence. At the same time, they continue to be supported, motivated, and accompanied to be more developed. Mentors ensure that every task received by participants is "limited" in number, yet "deep" the mastery of the material, so that participants do not think it as a burden when expressing because of the wide range of material presentation.

When participants get clear assignments, they no longer feel confused about learning (i.e. the material for compiling a performance assessment item/indicator for learning evaluation material). Participants are more selective in choosing and sorting material and what stages need to be prepared to make presentations later. At the same time, participants' sense of responsibility is established, both for themselves and for the group discussion or study group. Educators and mentors are aware of the task neglect can occur, therefore clarity of time is also set so that participants can prepare earlier and 
be more mature in order to do their best for performance. Challenging learning experiences through clear work assignments run well, as long as participants don't feel pressure. Participant 5 (Male 21 years old) stated that: "As long as I get the trust from other people (group leader or educator), I do not think the task as a pressure." Thus, as long as the participants get a clear task, they can improve their self-confidence because the mastery of the material can be more leverage (Blegur, Mae, \& Souisa, 2018:78).

Participants who have trust irritation will not be maximized if a lecturer gives them an abstractive assignment. They will be confused to start because they are not able to manage their self-potential. The number of tasks given and or performed by participants is not a guarantee that they will master a material however what is important is that they understand the principles of solving the problems or tasks given. Those principles are the navigators for participants to complete and succeed in completing and even mastering certain problem-solving strategies. Simply, the tasks distributed to participants must be followed by various solution strategies so that their depth and critical thinking encourages their enthusiasm for expression becomes more essential than the "stack" of tasks without considering the quality of thinking, work quality, and the quality of expression of the participants.

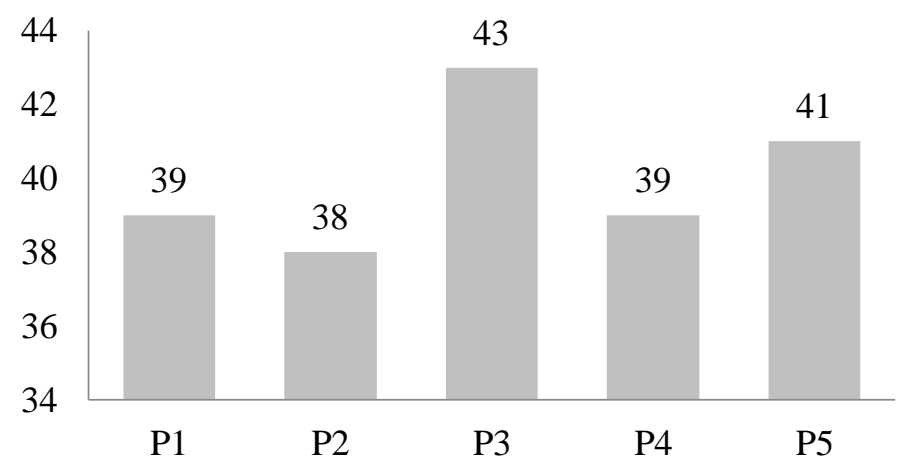

Figure 1. Participants' self-confidence index for cycle 1

The actions taken as an effort to restore participants' self-confidence in first cycle with three implementation actions have not been successful, in which all participants did not meet the required completeness criteria. In first cycle, each participant obtained a self-confidence index of, $\mathrm{P} 1=39, \mathrm{P} 2=38$, $\mathrm{P} 3=43, \mathrm{P} 4=39$, and $\mathrm{P} 5=41$. Thus, action in the second cycle must be done so that the participants' self-confidence index can be restored in line with the criteria. Participants still need a number of other more acceptable actions with the restoration needs of self-confidence based on the action results in cycle 1 . 


\section{Action for Cycle 2 \\ Give total trust}

Participants who get the task without any follow-up in form of selfexpression do not have any effect on their self-confidence. The work worked on must be used as a way to train self-confidence. In this sense, educators or mentors do not use the tasks as "piles" of paper coloring learning activities, yet as a password for participants to show the quality of their self-confidence. Participants have attempted to complete the task so that they need to get the opportunity to prove the quality of their work to others. They will give assurance to others that what is produced is truly satisfying and/or vice versa. For some students, they even yearn for expressive momentum (e.g. oral presentations) to steal the attention of others because they have the same abilities as others. Even according to Tlonaen \& Blegur (2017:228), when students believe in their abilities, this has become asset to succeed when they perform.

The next step used to restore students' self-confidence is to give them total trust. Starting from the existence of clear work assignments, participants are given trust so that they become "key" in discussion or presentation activities. The key means that to make participants as pioneers in any activity, whether as questioners, debaters, or the first presenter of other presenters. Participants are always given the main opportunity to do activities relating to the learning process, for instance by asking: "Do you have questions to ask? Do you want to answer this question? Or we will do the presentation later, thus you must prepare for the presentation so that our group gives the best." This is not an insistence, but a mentor gives the opportunity to participants to judge themselves honestly and train participants to think positively of a set of knowledge and skills that they have. The participants believe that the trust gives an opportunity for them to provide evidence that they deserve to do the task as is performed by other students.

Participants' self-confidence can be good when people trust them, because self-confidence is a positive and realistic view of themselves (Reddy, 2014:56), and about the expression of self-ability in the form of selfevaluation. Participant 3 (Male, 24 years old) even hoped that: "Don't take back the trust or assignments that have been provided to me, this will actually undermine my self-confidence because I assume that I do not have the ability if someone replaces me." Remember that the learning process is a process of improvement, thus give participants the opportunity to be more open, active, and expressive to express their views or ideas and control their potential during the learning process. Intention and purpose must be based on emotional support (Burleson, 2003:1), so that if there is a mistake, the mentor and educator make improvements instead of moking them. If this is left unchecked, then it will be an "experience" for the learning atmosphere because 
educators or other students legalize ridicule behavior (Tlusciak-Deliowska, 2016:167). Actually, the research by Blegur (2017:140) has proven that students who successfully carry out their beliefs (presentations) feel happy and satisfied with their abilities. The fact, self-confidence encourages students to become more active, participatory, and actual when dealing with tasks relating to performance.

\section{Be evaluative not justificative}

Mentors are always reminded that one of the roles they play in the mentoring process is as an evaluator. The task and role of the mentor is not to justify (judge) participants, yet to evaluate (improve) the knowledge and skills that participants have shown. Moreover, the problem faced by participants is the irritation of self-confidence thus what they need is improvements so that participants become more critical and creative because they believe in their academic capacity. Participant 5 (Male, 21 years) stated that: "Evaluations that can help my performance in increasing my self-confidence are positive evaluations and motivations that are able to process one's personality to develop their inner potential." Participants not only need results from the performance they show but more than that namely the content or solution of what action they need to improve to show a change in a constructive direction. Then the evaluation that "frees" participants is more required to restore their self-confidence, rather than justifications for the efforts they have made.

This evaluation activity is based on observation guidelines that educators have provided and shared with students in each study group. There are 10 important components, ranging from the appearance of the self to the management of the class when presenting material (acting as a presenter). There were no students missed the presentation activities, even though they worked in discussion groups meaning that even though in groups, all members have the same role and capacity, the difference is only in the content of the material presented. The data obtained through this observation guide is then used to make improvements to the performance that the participants have achieved. Point to remember that before this evaluation activity was carried out, mentor should ensure the participant's openness to receive input, participants knew their work assignments, and participants had gained good trust from the mentor and fellow students in the discussion group. This is just a strategy to ensure participants still have self-confidence when evaluated by a mentor.

The evaluation the mentor does provide emotional and supportive assistance to the participants so that there is a spirit of learning within them (Burleson, 2003:1). The mentor begins by exploring the areas that become the strengths of participants when expressing (asking, answering, or making presentations). Some examples include: "Your question is good, you need to 
focus more to perfect it." There are also others: "You have well-presented the material, we enjoy it. If you are more active in mastering the class, your performance becomes more impressive." The mentor sees every advantage that participants have, and then use it to embroider participants' performance negligence. Mentors try to change the way other students think that tends to focus on negligence or weakness. Though in fact, this does not help participants when restoring their self-confidence and self-esteem. The mentors have ensured and guaranteed the participants that they have advantages, thus this triggers participants' enthusiasm and self-confidence to continue to improve themselves to be more advanced through collaborative activities.

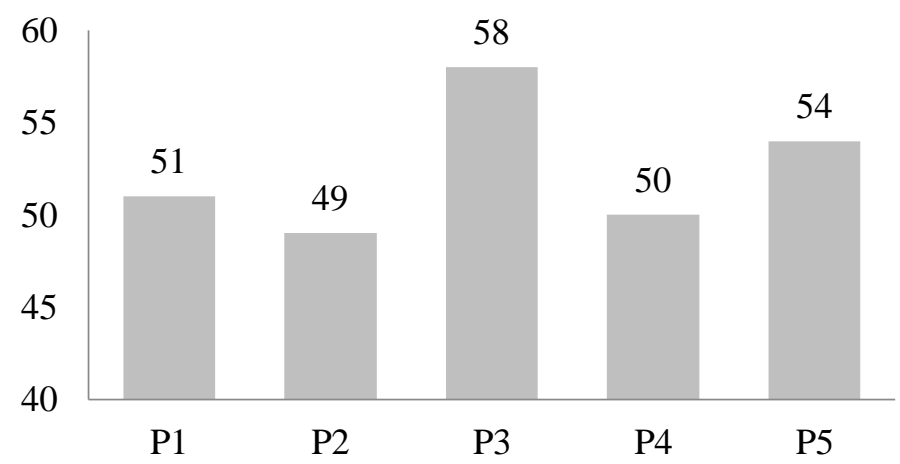

Figure 2. Participants' self-confidence index for cycle 2

From the two actions implemented in second cycle, participants received the self-confidence index as follows: $\mathrm{P} 1=51$ (increase of $18.75 \%$ ), $\mathrm{P} 2=49$ (increase of $17.1875 \%$ ), $\mathrm{P} 3=58$ (increase of $23.4375 \%$ ), $\mathrm{P} 4=50$ (increase of $17.1875 \%$ ), and P5 $=54$ (increase of 20.3125\%) . This result explains that action research is complete because all participants have succeeded in fulfilling the completeness criteria determined in table 1.

\section{Cycles of Peer Mentoring Strategy in Restoring Students' Self- Confidence}

From five restoration strategies, in two cycles applied, namely: 1) Limited and intimate peer groups, 2) Peers who are caring, supportive and inspirational, 3) There are clear or detailed work assignments, 4) Give full trust, and 5) Evaluative attitude in nature, not just justification is able to restore students' self-confidence in learning process. For instance students begin to have a sense of trust in their own abilities, act independently in making decisions, have a positive sense of self, and begin to have courage in expressing their opinions. Peer mentoring has bridged students to develop due to the support from caring, supportive, and motivating peers. Designing limited group makes students no longer feel awkward, because they are among people who are limited in a populative manner. The fewer people and 
increasingly non-formal discussion processes, the more free students express themselves, including being able to give ideas when they are asked or get opportunities from other groups, be responsible for assigned tasks, and are no longer ashamed to maintain eye contact with others when communicating.

Peer mentoring is able to restore students' self-confidence in learning process, so that educators or students need to abandon non-supportive, nonmotivating, and justified behaviors so that there is no more anxiety when students want to express themselves (Blegur, Mae, \& Souisa, 2018:80). Prioritize small group learning and mentoring oriented towards training experience, self reflection, supportive evaluation, and feedback in order to enliven interaction, self-confidence, and interpersonal skills of students (Sprengel \& Job, 2004:246; Skinner, Hyde, McPherson, \& Simpson, 2016:21), and provide high psycho-social support (Grant-Vallone \& Ensher, 2000:637). Peer mentoring is also as an alternative to foster learning and improve students' communication and leadership skills due to the presence of mentors and mentees (Grimes, Baker, \& Kuczmarski, 2014:1286), to improve presentation skills (Jerome, Baker, \& Fang, 2018:979), there is change in selfesteem, social skills, and behavioral competencies (Karcher, 2005:65), as well as peer mentoring is also proven to reduce students' anxiety (Saifman \& Whigham, 2014:120; Cropp, 2017:481).

The implementation of good peer mentoring can also improve networking and reduce or avoid students from various failures in the learning process (Grimes, Baker, \& Kuczmarski, 2014:1286). In addition, with good self-confidence, students' work accuracy are easily predictable (Kleitman \& Stankov, 2005:161) while students use various strategies to improve the quality of their learning, such as recording, summarizing, reflecting, reading, and reviewing the tasks they learn (Kisac \& Budak, 2014:3336). In this sense, participants who are more adaptive with peer mentoring strategies have better learning outcomes (Bernier, Larose, \& Soucy, 2005:29), thus it is appropriate that educators pay attention to the mentoring process that is friendly, nurturing, open minded, and trusting (Beyene, Anglin, Sanchez, \& Ballou, 2011:87) so that the learning process becomes more useful for the balance of students' learning outcomes. 


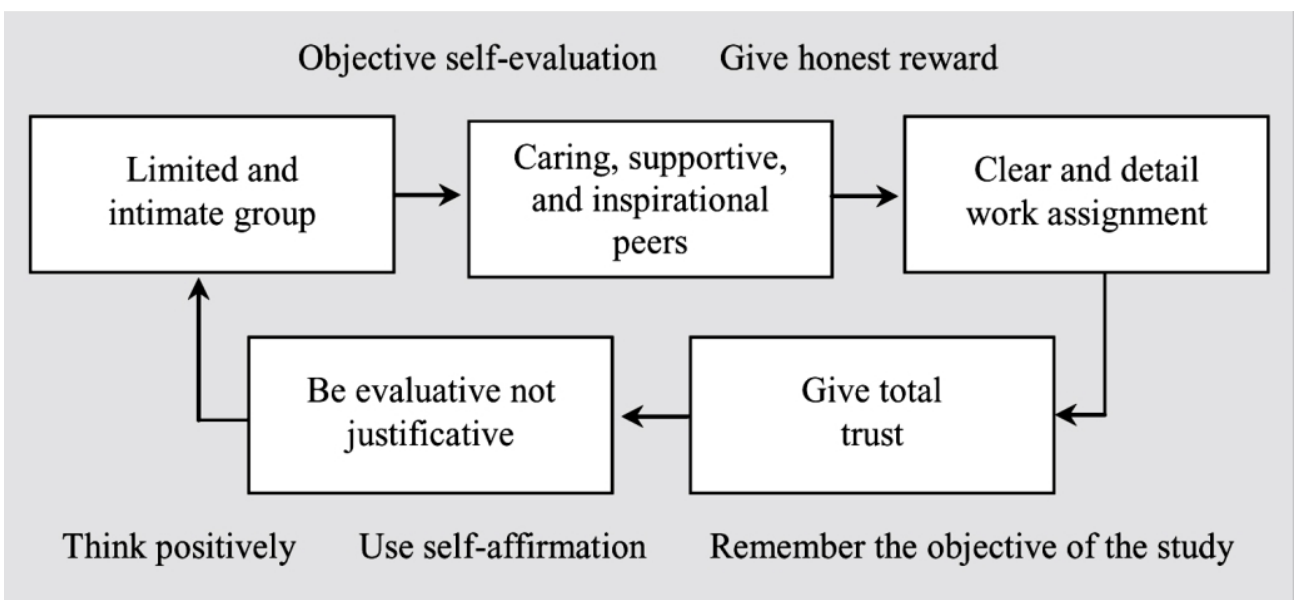

Figure 3. A cycle of peer mentoring strategies and the role of participants in the process of self-confidence restoration

\section{Conclusion}

Educators need to empower fellow students to affirm and create openness and authenticity of information on their negligence which hinders the productivity of learning quality. The results of the study have guaranteed that the peer mentoring strategy is effective to restore students' selfconfidence, such as: 1) Determination of a limited and intimate discussion or study group between mentors and participants, 2) Ensuring that each group member has a caring, supportive and inspiring attitude to stimulate participants to be more open, 3) There is clarity when providing assignments to participants to keep their focus and mood to continue learning, 4) Give total trust to participants so that they become the main figures in the discussion group in order to use the opportunity and to a self-proof, and 5) Evaluation of participants' performance based on the eagerness for improvement rather than negligence-based assessments because of the participants. This strategy takes place step by step so that it avoids leapfrogging stages so that participants can perceive each restoration progress well and more strengthen from each stage they have experienced.

Peer mentoring helps many educators and students to control the quality of learning. Participants are not only taught how to become competent and professional candidates for educators, yet they can also play a role through the learning experiences that they experience themselves directly, such as as peers while participating in overcoming the problem of distrust from other people (their own partners). The strategy applications will assist them when they later become real educators at the school. This is also one of the educational concepts of the present era, in which the role of educators will be more as a character modifier for the learners, and when students implement well as peers in restoring participants' self-confidence, then the students have 
helped their partners by supporting positive self-character to face the rapid progress and competitive era.

\section{Acknowledgement}

Researcher team say much gratitude to Peggy M. Jonathans, S.Pd., M.A., as the Head of the Gender Task Force who has sponsored activities on internal gender research, to Wilson L. Tisera, M.Si., Ph.D., as the Head of the Research Institute who has facilitated the process of controlling and evaluating the final report and research articles of the research team, to June A. Jacob, S.Pd., M.A., as Dean of the Teaching and Education Faculty and to Agustinus J. Nafie, S.Pd., M.Or., as Chair of the Physical Education, Health, and Recreation Study Program who is pleased to give permission and support the entire research process.

\section{References:}

1. Al-Hebaish, S. M. (2012). The correlation between general selfconfidence and academic achievement in the oral presentation course. Theory and Practice in Language Studies, 2(1), 60-65.

2. Allen, T. D., Russell, J. E. A., \& Maetzke, S. B. (1997). Formal peer mentoring: Factors related to proteges' satisfaction and willingness to mentor others. Group and Organization Management, 22(4), 488-507. https://doi.org/10.1177/1059601197224005

3. Badu, A. A. M. (2010). Pengembangan model pelatihan pendampingan dalam rangka peningkatkan kompetensi pendamping: Studi pada kelompok usaha konveksi di Kota Gorontalo. Disertasi Doktoral, Universitas Pendidikan Indonesia, Bandung.

4. Bernier, A., Larose, S., \& Soucy, N. (2005). Academic mentoring in college: The interactive role of student's and mentor's interpersonal dispositions. Research in Higher Education, 46(1), 29-51. https://doi.org/10.1007/s11162-004-6288-5

5. Beyene, T., Anglin, M., Sanchez, W., \& Ballou, M. (2011). Mentoring and relational mutuality: Protégés' perspectives. The Journal of Humanistic Counseling, Education and Development. 41(1), 87-102. https://doi.org/10.1002/j.2164-490X.2002.tb00132.X

6. Blegur, J. (2017). "Eksplorasi motivasi belajar peserta didik dengan mediasi metode mengajar." Seminar Hasil Penelitian Pendidikan. Pemberdayaan Hasil Penelitian melalui Seminar: Mendorong Peningkatan Penulisan Artikel dan Publikasi (hal. 140-150), Universitas Negeri Jakarta, Indonesia.

7. Blegur, J., Mae, R. M., \& Souisa, M. (2018). "I feel anxious when communicating: Questionning students' learning readiness." International Conference on Technology, Education, and Social 
Science (pp. 75-85), Slamet Riyady University, Surakarta, Indonesia. Retrieved from: http://ejurnal.unisri.ac.id/index.php/proictss/article/view/2142

8. Blegur, J., Manu, T. S. N., \& Souisa, M. (2018). Students' disciplined character as the effort to improve self-esteem and academic performance. International Journal of Academic Research in Business and Social Sciences, 8(4), 366-376. http://dx.doi.org/10.6007/IJARBSS/v8-i4/4019

9. Blegur, J., Wasak, M. R. P., Tlonaen, Z. A., \& Manggoa, M. A. (2017). Students' behaviour of indiscipline syndrome in teaching and learning process. Educational Administration Research and Review Journal, 1(2), 37-41. Retrieved from: http://ejournal.upi.edu/index.php/EAR/article/view/7467

10. Bryant, S. E. (2002). The impact of peer mentoring on organizational knowledge creation and sharing: An empirical study in a software firm. Group and Organization Management, 30(3), 319-338. https://doi.org/10.1177/1059601103258439

11. Burleson, B. R. (2003). The experience and effects of emotional support: What the study of cultural and gender differences can tell us about close relationships, emotion, and interpersonal communication. Personal Relationship, 10(1), 1-23. https://doi.org/10.1111/1475$\underline{6811.00033}$

12. Cornu, R. L. (2005). Peer mentoring: Engaging pre-service teachers in mentoring one another. Mentoring \& Tutoring: Partnership in Learning, 13(3), 355-366. https://doi.org/10.1080/13611260500105592

13. Creswell, J. W. (2009). Research design: Qualitative, quantitative, and mixed approaches (3rd ed). Thousand Oaks, California: SAGE Publications.

14. Cropp, I. (2017). Using peer mentoring to reduce mathematical anxiety. Research Papers in Education, 32(4), 481-500. https://doi.org/10.1080/02671522.2017.1318808

15. Dhall, S. (2013). Self-confidence and academic achievement as predictor of intelligence. Indian Journal of Education and Information Management, 2(3), 555-556. Retrieved from: http://ijeim.informaticspublishing.com/index.php/ijeim/article/view/3 4406

16. Glass, N., \& Walter, R. (2000). An experience of peer mentoring with student nurses: Enhancement of personal and professional growth. Journal of Nursing Education, 39(4), 155-160. https://doi.org/10.3928/0148-4834-20000401-05 
17. Grant-Vallone, E. J., \& Ensher, E. A. (2000). Effects of peer mentoring on types of mentor support, program satisfaction and graduate student stress: A dyadic perspective. Journal of College Student Development, 41(6), 637-642.

18. Grimes, M. E., Baker, S. D., \& Kuczmarski, M. F. (2014). Peer mentoring contributes to career growth of undergraduate nutrition and dietetics students. Creative Education, 5, 1286-1295. doi: 10.4236/ce.2014.514147.

19. Hanafiah, N., \& Suhana, C. (2010). Konsep strategi pembelajaran (cet. 2). Bandung: Refika Aditama.

20. Hannula, M. S., Maijala, H., \& Poehkonen, E. (2004). Development of understanding and self-confidence in mathematics; grades 5-8. PME, $3,17-24$.

21. Hatzigeorgiadis, A., Zourbanos, N., Mpoumpaki, S., \& Theodorakis, Y. (2009). Mechanisms underlying the self-talk-performance relationship: The effects of motivational self-talk on self-confidence and anxiety. Psychology of Sport and Exercise, 10, 186-192. https://doi.org/10.1016/j.psychsport.2008.07.009

22. Hoover, N. L., O'Shea, L. J., \& Carroll, R. G. (1988). The supervisorintern relationship and effective interpersonal communication skills. Journal of Teacher Education, 39(2), 22-27. https://doi.org/10.1177/002248718803900205

23. Jerome, D., Baker, S., \& Fang, C-S. (2018). Peer teaching promotes improved knowledge and attitudes about myplate and supertracker among college students and increases self-efficacy in peer nutrition educators. Creative Education, 9(6), 979-992. DOI: 10.4236/ce.2018.96072

24. Karcher, M. J. (2005). The effects of developmental mentoring and high school mentors' attendance on their younger mentees' selfesteem, social skills, and connectedness. Psychology in the Schools, 42(1), 65-77. https://doi.org/10.1002/pits.20025

25. Karimi, A., \& Saadatmand, Z. (2014). The relationship between selfconfidence with achievement based on academic motivation. Kuwait Chapter of Arabian Journal of Business and Management Review, 4(1), 210-215.

26. Kemmis, S., \& McTaggart, R. (1988). The action research planner (3rd ed). Victoria: Deakin University.

27. Kisac, I., \& Budak, Y. (2014) Metacognitive strategies of the university students with respect to their perceived self-confidence levels about learning. Procedia-Social and Behavioral Sciences, 116(21), 3336-3339. https://doi.org/10.1016/j.sbspro.2014.01.759 
28. Kleitman, S., \& Stankov, L. (2007). Self-confidence and metacognitive processes. Learning and Individual Differences, 17, 161-173.

29. Kumar, A., \& Teotia, A. K. (2017). Constructivism: A dynamic approach of teachinglearning social science at upper primary level. International Journal of Management and Applied Science, 3(5), 135139.

30. Lester F. K., Garofalo J., \& Kroll, D. L. (1989). Self-confidence, interest, beliefs, and metacognition: Key Influences on problemsolving behavior. In: McLeod D. B., \& Adams V. M. (eds). Affect and mathematical problem solving (pp. 75-88). New York: Springer https://doi.org/10.1007/978-1-4612-3614-6_6

31. Murni, S. M., Suswati, R., \& Solin, M. (2013). Pendampingan guru menggunakan bahasa Inggeris dalam mengajar di sekolah berstandar internasional Al Azhar Medan. Jurnal Tematik, 3(12), 1-22. DOI: https://doi.org/10.24114/jt.v3i1.1205

32. Pearce, W. B. (2009). Trust in interpersonal communication. Speech Monographs, 41(3), 236-244. https://doi.org/10.1080/03637757409375842

33. Reddy, M. M. (2014). A study of self confidence in relation to achievement motivation of d.ed students. Global Journal for Research Analysis, 3(8), 56-58.

34. Rizka, M. A. (2013). Model pendampingan anak jalanan (Studi kasus di lembaga swadaya masyarakat "rumah impian"). Jurnal Kependidikan, 12(2), 161-170.

35. Saifman, H., \& Whigham, M. (2014). "The influence of peer mentoring on anxiety, self-confidence and priority setting of baccalaureate student nurses in the simulation lab setting." Ron and Kathy Asssaf College of Nursing Proceedings, Presentations, Posters, Speeches, Lectures, etc ( $p$. 120). Retrieved from: https://nsuworks.nova.edu/hpd_con_facpres/120

36. Skinner, K. L., Hyde, S. J., McPherson, K. B. A., \& Simpson, M. D. (2016). Improving students interpersonal skills through experiential small group learning. Journal of Learning Design, 9(1), 21-36. Retrieved from: https://www.learntechlib.org/p/175701/

37. Sprengel, A., \& Job, L. (2004). Reducing student anxiety by using clinical peer mentoring with beginning nursing students. Nurse Educator, 29(6), 246-250. DOI: 10.1097/00006223-200411000-00010

38. Tlonaen, Z. A., \& Blegur, J. (2017). Konsep diri akademik mahasiswa pascasarjana. Scholaria: Jurnal Pendidikan dan Kebudayaan, 7(3), 226-233. DOI 10.24246/j.scholaria.2017.v7.i3.p226-233 
39. Tlusciak-Deliowska, A. (2016). School experiences retrospectively: Relationship between recall of bullying experiences and perception of schools by pedagogy students. The New Educational Journal Review, 43, 167-177. DOI: 10.15804/tner.2016.43.1.14

40. Wahyuni, S. (2014). Hubungan antara kepercayaan diri dengan kecemasan berbicara di depan umum pada mahasiswa psikologi. $e$ Journal Psikologi, 2(1), 50-64.

41. Wasak, M. R. P., Manggoa, M. A., \& Blegur, J. (2016). "Perilaku indisipliner peserta didik dan implikasinya dalam proses belajarmengajar." Seminar Nasional Psikologi Indigenous 2016 (hal. 433449), Universitas Negeri Malang, Indonesia.

42. Widati, M. (2012). Peningkatan profesional dan kemampuan menyusun proposal ptk melalui pendampingan bagi guru kelas $\mathrm{v}$ sd. Jurnal Manajemen Pendidikan, 7(2), 119-124.

43. Wildan, M. A., Irawati, A., \& Arista, E. (2014). The effect of self confidence, self-esteem, and self concept on the student's job readiness in the universities through Gerbang Kertasusila Region, Indonesia. Australian Journal of Basic and Applied Sciences, 8(23), 196-199. 
Appendix 1. Guidelines for observing self-confidence

Statements educators with pleasure.

2. Complete academic assignments on time or on target.

3. Playing the role well in the discussion process (speaker, moderator, or debater).

$\begin{array}{llll}4 & 3 & 2 & 1\end{array}$
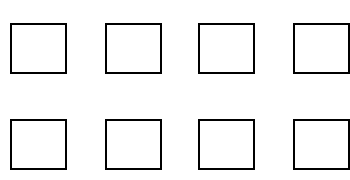

4. Able to assess yourself honestly and objectively to improve thecompetence.

5. Able to make informed decisions in urgent situations during the discussion.
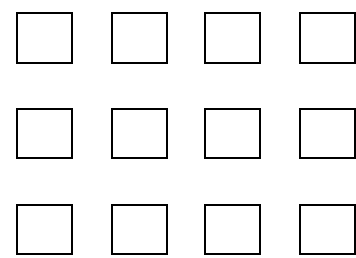

6. Responsible for the development of the tasks that have been carried out during the discussion activities.

7. Have the initiative to appear, when randomly appointed by educators.

8. Answer questions or criticisms clearly and in detail.

9. Mastering the class well when delivering material.

10. Stay calm towards self-defeating criticism during discussions.

11. Be friendly when getting the criticism of the material presented.

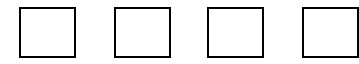

12. Don't blame others, when there are obstacles, mistakes in learning.
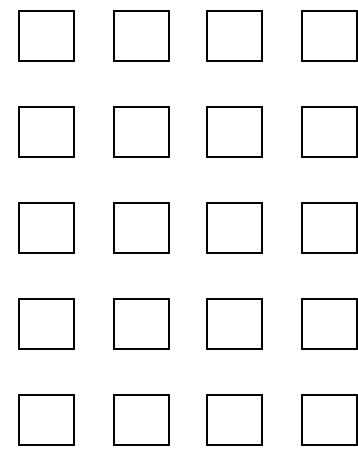

13. Always want to ask questions when getting the opportunity from a moderator or educator.

14. Dare to ask questions to peers or educators when they feel unclear.
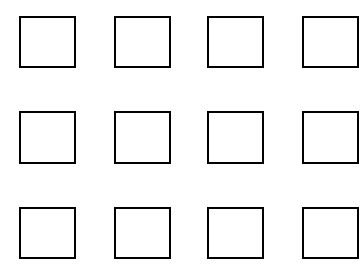

15. Maintain eye contact with the speaker when expressing opinions.

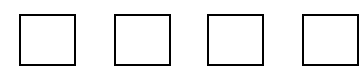

16. Provide questions or objections with accentuation of clear tones and gestures. 